\title{
Front Matter: Volume 6805
}

, "Front Matter: Volume 6805," Proc. SPIE 6805, Three-Dimensional Image Capture and Applications 2008, 680501 (14 March 2008); doi:

10.1117/12.790578

SPIE. Event: Electronic Imaging, 2008, San Jose, California, United States 


\title{
PROCEEDINGS
}

Electronic

Imaging

Sclence and Tochnology

\section{Three-Dimensional Image Capture and Applications 2008}

\author{
Brian D. Corner \\ Masaaki Mochimaru \\ Robert Sitnik \\ Editors
}

28-29 January 2008

San Jose, California, USA

Sponsored and Published by

IS\&T-The Society for Imaging Science and Technology

SPIE 
The papers included in this volume were part of the technical conference cited on the cover and title page. Papers were selected and subject to review by the editors and conference program committee. Some conference presentations may not be available for publication. The papers published in these proceedings reflect the work and thoughts of the authors and are published herein as submitted. The publishers are not responsible for the validity of the information or for any outcomes resulting from reliance thereon.

Please use the following format to cite material from this book:

Author(s), "Title of Paper," in Three-Dimensional Image Capture and Applications 2008, edited by Brian D. Corner, Masaaki Mochimaru, Robert Sitnik, Proceedings of SPIE-IS\&T Electronic Imaging, SPIE Vol. 6805, Article CID Number (2008).

ISSN 0277-786X

ISBN 9780819469779

Copublished by

SPIE

P.O. Box 10, Bellingham, Washington 98227-0010 USA

Telephone +1 3606763290 (Pacific Time) · Fax +1 3606471445

SPIE.org

and

IS\&T-The Society for Imaging Science and Technology

7003 Kilworth Lane, Springfield, Virginia, 22151 USA

Telephone +1 7036429090 (Eastern Time) · Fax +1 7036429094

imaging.org

Copyright @ 2008, Society of Photo-Optical Instrumentation Engineers and The Society for Imaging Science and Technology.

Copying of material in this book for internal or personal use, or for the internal or personal use of specific clients, beyond the fair use provisions granted by the U.S. Copyright Law is authorized by the publishers subject to payment of copying fees. The Transactional Reporting Service base fee for this volume is $\$ 18.00$ per article (or portion thereof), which should be paid directly to the Copyright Clearance Center (CCC), 222 Rosewood Drive, Danvers, MA 01923. Payment may also be made electronically through CCC Online at copyright.com. Other copying for republication, resale, advertising or promotion, or any form of systematic or multiple reproduction of any material in this book is prohibited except with permission in writing from the publisher. The CCC fee code is $0277-786 \mathrm{X} / 08 / \$ 18.00$.

Printed in the United States of America.

Paper Numbering: Proceedings of SPIE follow an e-First publication model, with papers published first online and then in print and on CD-ROM. Papers are published as they are submitted and meet publication criteria. A unique, consistent, permanent citation identifier (CID) number is assigned to each article at the time of the first publication. Utilization of CIDs allows articles to be fully citable as soon they are published online, and connects the same identifier to all online, print, and electronic versions of the publication. SPIE uses a six-digit CID article numbering system in which:

- The first four digits correspond to the SPIE volume number.

- The last two digits indicate publication order within the volume using a Base 36 numbering system employing both numerals and letters. These two-number sets start with 00, 01, 02, 03, 04, 05, 06, 07, 08 , 09, OA, OB ... 0Z, followed by 10-1Z, 20-2Z, etc.

The CID number appears on each page of the manuscript. The complete citation is used on the first page, and an abbreviated version on subsequent pages. Numbers in the index correspond to the last two digits of the six-digit CID number. 


\section{Contents}

vii Conference Committee

\section{SESSION 1 HARDWARE I}

680502 Efficient acquisition and rendering of transparent and refractive objects using quotient image [6805-01]

K. Ochiai, N. Tsumura, T. Nakaguchi, Chiba Univ. (Japan); K. Miyata, National Museum of Japanese History (Japan); Y. Miyake, Chiba Univ. (Japan)

680503 Hybrid, contact, and no contact measurement system for industry [6805-02]

R. Sitnik, Warsaw Univ. of Technology (Poland); J. Stadek, M. Kupiec, Cracow Univ. of Technology (Poland); P. Błaszczyk, W. Załuski, Warsaw Univ. of Technology (Poland)

680504 Inspection of microchip mounting tolerances by 3D vision [6805-03]

S. Behler, M. von Arx, Oerlikon Assembly Equipment (Switzerland)

\section{SESSION 2 HARDWARE II}

680505 A flexible 3D vision system based on structured light for in-line product inspection [6805-04] $\varnothing$. Skotheim, J. O. Nygaard, J. Thielemann, SINTEF ICT (Norway); T. Vollset, Tordivel AS (Norway)

680506 Rapid 360 degree imaging and stitching of 3D objects using multiple precision 3D cameras [6805-05]

T. LU, JPL, CalTech (USA); S. Yin, The Pennsylvania State Univ. (USA); J. Zhang, Trellis

Bioscience (USA); J. Li, F. WU, Univ. of Northern California (USA)

680507 Rangefinding system using hybrid pattern projections [6805-06]

O. Kagiyama, Y. Sato, H. Saito, Keio Univ. (Japan)

680508 3D threat image projection [6805-08]

Y. O. Yildiz, D. Q. Abraham, Analogic Corp. (USA); S. Agaian, Univ. of Texas at San Antonio (USA); K. Panetta, Tufts Univ. (USA)

\section{SESSION 3 3D DATA PROCESSING AND ALGORITHMS I}

680509 Using hybrid approaches to solve the challenges of shape from shading [6805-09]

R. Murphy, Z. J. Wood, California Polyłechnic State Univ. (USA)

6805 0A An automatic alignment technique for multiple rangefinders [6805-10]

K. Fujiwara, K. Yamauchi, Y. Sato, Keio Univ. (Japan) 
6805 OB Depth maps: faster, higher and stronger? [6805-11]

I. A. Ideses, L. P. Yaroslavsky, B. Fishbain, Tel-Aviv Univ. (Israel)

SESSION 4 3D DATA PROCESSING AND ALGORITHMS II

6805 OD Improved linearity using harmonic error rejection in a full-field range imaging system [6805-13]

A. D. Payne, A. A. Dorrington, M. J. Cree, Univ. of Waikato (New Zealand); D. A. Carnegie, Victoria Univ. of Wellington (New Zealand)

6805 OE Denoising techniques for raw 3D data of TOF cameras based on clustering and wavelets [6805-14]

B. Moser, Software Competence Ctr. Hagenberg (Austria); F. Baver, Univ. of Linz (Austria);

P. Elbau, Johann Radon Institute for Computational and Applied Mathematics (Austria);

B. Heise, Univ. of Linz (Austria); H. Schöner, Software Competence Ctr. Hagenberg (Austria)

6805 OF Locating the source of topological error in reconstructed 3D models [6805-15]

E. Firestone, C. Povey, Z. J. Wood, California Polytechnic State Univ. (USA)

$68050 G \quad$ Using quality metrics with laser range scanners [6805-16]

D. MacKinnon, Carleton Univ. (Canada) and National Research Council Canada

(Canada); V. Aitken, Carleton Univ. (Canada); F. Blais, National Research Council Canada

(Canada)

\section{SESSION 5 ENVIRONMENT SCANNING}

$6805 \mathrm{OH} \quad$ Estimating building floor plans from exterior using laser scanners [6805-17]

M. Johnston, A. Zakhor, Signetron, Inc. (USA)

$68050 \mathrm{Ol} \quad$ Reconstruction of 3D indoor model by scalable sensing using mobile robot [6805-18]

K. Fujimoto, The Univ. of Electro-Communications (Japan); F. Beniyama, T. Moriya, Hitachi,

Ltd. (Japan); Y. Nakayama, The Univ. of Electro-Communications (Japan)

\section{SESSION 6 3D PRINTING AND DISPLAY}

6805 0J Optical implementation of improved resolution with intermediate-view reconstruction technique based on integral imaging [6805-19]

K.-J. Lee, Kwangwoon Univ. (South Korea); S.-T. Lee, Presidential Security Service (South

Korea); Y.-S. Oh, S.-P. Hong, C.-K. Kim, E.-S. Kim, Kwangwoon Univ. (South Korea)

$6805 \mathrm{OL} \quad$ Specifying colour and maintaining colour accuracy for 3D printing [6805-21]

C. Parraman, P. Walters, B. Reid, D. Huson, Univ. of the West of England (United Kingdom)

\section{SESSION 7 HUMAN SCANNING I}

6805 OM A novel sensor system for 3D face scanning based on infrared coded light [6805-22]

D. Modrow, C. Laloni, G. Doemens, Siemens AG (Germany); G. Rigoll, Technische Univ. München (Germany) 
6805 ON Comparison of Cyberware PX and PS 3D human head scanners [6805-23]

J. Carson, B. D. Corner, U.S. Army Natick Soldier RDEC (USA); E. Crockett, Univ. Massachusetts, Dartmouth (USA); P. Li, SAIC (USA); S. Paquette, U.S. Army Natick Soldier RDEC (USA)

6805 OP A calibration method of multiple rangefinders system [6805-25]

H. Kameshima, Y. Sato, H. Saito, Keio Univ. (Japan)

$68050 Q$ 3D monitoring of the intraoperative brainshift by means of photogrammetry [6805-26] N. D'Apuzzo, Hometrica Consulting (Switzerland); M. Verius, Univ. Klinik f. Radiodiagnostik II, Univ. Innsbruck (Austria)

\section{SESSION 8 HUMAN SCANNING II}

6805 OR An efficient stochastic framework for 3D human motion tracking [6805-27]

B. Ni, S. Winkler, A. A. Kassim, National Univ. of Singapore (Singapore)

6805 OS FaceTOON: a unified platform for feature-based cartoon expression generation [6805-28]

T. Zaharia, Institut TELECOM (France); O. Marre, Quadraxis Co. (France); F. Prêteux,

P. Monjaux, Institut TELECOM (France)

6805 OT Person and gesture tracking with smart stereo cameras [6805-29]

G. Gordon, X. Chen, R. Buck, TYZX, Inc. (USA)

$68050 \mathrm{U}$ Intelligent noncontact surgeon-computer interface using hand gesture recognition [6805-30]

M. Zhao, Ełonnet, Inc. (USA); A. G. Nowatzyk, Cedars-Sinai Medical Ctr. (USA); T. LU,

Etonnet, Inc. (USA); D. L. Farkas, Cedars-Sinai Medical Ctr. (USA)

INTERACTIVE PAPER SESSION

6805 OW Distributed RANSAC for 3D reconstruction [6805-32]

M. XU, M. Petrou, Imperial College London (United Kingdom)

$68050 X$ Analyzing the influence of camera temperature on the image acquisition process [6805-33] H. Handel, Univ. of Mannheim (Germany)

$68050 Y$ 3D reconstruction and spatial auralization of the Painted Dolmen of Antelas [6805-34] P. Dias, G. Campos, Univ. of Aveiro (Portugal) and Instituto de Engenharia Electrónica e Telemática de Aveiro (Portugal); V. Santos, R. Casaleiro, R. Seco, Univ. of Aveiro (Portugal); B. Sousa Santos, Univ. of Aveiro (Portugal) and Instituto de Engenharia Electrónica e Telemática de Aveiro (Portugal)

$68050 Z$ A method for converting three-dimensional models into auto-stereoscopic images based on integral photography [6805-35]

M. Katayama, Y. Iwadate, NHK Science \& Technical Research Labs. (Japan) 
680510 Synthesis of arbitrary viewpoint image from images of multiple weakly calibrated camera images using all in-focus rendering method [6805-36]

Y. Matsumura, Y. Sakamoto, Hokkaido Univ. (Japan)

680511 High-speed depth-mapping axi-vision camera with compact optical system [6805-37]

T. Aida, T. Uragaki, Osaka City Univ. (Japan); M. Kawakita, NHK Science \& Technical

Research Labs. (Japan); Y. Tomita, R. Tsunoi, NHK Engineering Service Inc. (Japan);

S. Yahagi, M. Tanaka, Fujinon Corp. (Japan); H. Mitake, Shinko Electric Co., Ltd. (Japan);

M. Tawara, Visual Design Co., Ltd. (Japan)

680512 Small 3D image capturing system by TOMBO [6805-38]

K. Yamada, Hiroshima Institute of Technology (Japan); H. Takahashi, Osaka City Univ. (Japan)

680513 Priority depth fusion for the 2D to 3D conversion system [6805-39]

Y.-L. Chang, W.-Y. Chen, J.-Y. Chang, Y.-M. Tsai, C.-L. Lee, L.-G. Chen, National Taiwan Univ. (Taiwan)

Author Index 


\title{
Conference Committee
}

\author{
Symposium Chair \\ Nitin Sampat, Rochester Institute of Technology (USA) \\ Conference Chairs \\ Brian D. Corner, U.S. Army Soldier Systems Center (USA) \\ Masaaki Mochimaru, National Institute of Advanced Industrial \\ Science and Technology (Japan) \\ Robert Sitnik, Politechnika Warszawska (Poland)
}

Session Chairs

1 Hardware I

Brian D. Corner, U.S. Army Soldier Systems Center (USA)

2 Hardware II

Robert Sitnik, Politechnika Warszawska (Poland)

3 3D Data Processing and Algorithms I

Masaaki Mochimaru, National Institute of Advanced Industrial Science and Technology (Japan)

$4 \quad 3$ D Data Processing and Algorithms II

Brian D. Corner, U.S. Army Soldier Systems Center (USA)

5 Environment Scanning

Brian D. Corner, U.S. Army Soldier Systems Center (USA)

63 3 Printing and Display

Robert Sitnik, Politechnika Warszawska (Poland)

7 Human Scanning I

Masaaki Mochimaru, National Institute of Advanced Industrial Science and Technology (Japan)

8 Human Scanning II

Brian D. Corner, U.S. Army Soldier Systems Center (USA) 
Downloaded From: https://www.spiedigitallibrary.org/conference-proceedings-of-spie on 26 Apr 2023

Terms of Use: https://www.spiedigitallibrary.org/terms-of-use 